\title{
IKLIM KOMUNIKASI ORGANISASI DI KANTOR IMIGRASI KELAS II LHOKSEUMAWE
}

\author{
Oleh \\ Muhammad Yahya ${ }^{1}$ \& Widia Yulibar \\ myahya@gmail.com \\ 1. Dosen Program Studi Ilmu Komunikasi Universitas Malikussaleh
}

\begin{abstract}
Abstrak
Penelitian ini menfokuskan pada Iklim Komunikasi Organisasi yang berlangsung antara atasan yaitu kepala urusan Wasdakim dengan bawahan atau pegawai dibidang kerja yang berhubungan langsung dengan pembuatan paspor mulai dari pengambilan foto, wawancara dan penyerahan di loket pelayanan, komunikasi yang berlangsung antara bawahan dengan atasan dan juga komunikasi horizontal di Kantor Imigrasi Kelas II Lhokseumawe. Iklim adalah suatu keadaan atau suasana yang dapat mempengaruhi perubahan sikap dan sifat dari individu maupun kelompok dalam suatu wilayah tertentu. Tujuan dari penelitian ini adalah untuk mengetahui iklim komunikasi organisasi yang berlangsung di kantor Imigrasi Kelas II Lhokseumawe. Penelitian ini menggunakan pendekatan penelitian kualitatif yang bersifat deskriptif dengan menggunakan teori sistem. Untuk memperoleh data dan informasi yang akurat maka metode yang digunakan dalam penelitian ini adalah wawancara dan observasi. Teknik analisis data yang digunakan dalam penelitian ini adalah mereduksi data, penyajian data dan penyimpulan data. Hasil penelitian ini memperlihatkan bahwa Iklim komunikasi berjalan kondusif secara keseluruhan. Hasil penelitian selanjutnya juga menggambarkan bahwa atasan jarang memberi pengarahan langsung kepada bawahan karena menurut atasan bawahan sudah mengerti dengan setiap tugas yang dikerjakan. bawahan tidak sepenuhnya terbuka, bawahan selalu menunggu atasan yang bertanya dulu baru menyampaikan keluhannya, komunikasi yang berlangsung juga jarang terjadi disebabkan karena atasan yang sibuk dengan pekerjaannya.
\end{abstract}

Kata Kunci : $\quad$ Iklim Komunikasi, Komunikasi Organisasi, Kantor Imigrasi Kelas II Lhokseumawe

\section{Pendahuluan}


Komunikasi tidak hanya menjadi kebutuhan hidup dan berlangsung pada diri seseorang namun komunikasi juga sangat dibutuhkan pada kehidupan berorganisasi. Karena komunikasi yang baik akan menentukan berjalan atau tidaknya sebuah organisasi. Dalam organisasi komunikasi berperan sangat penting. Karena dengan komunikasi tujuan organisasi itu akan mudah dicapai. Tanpa ada komunikasi maka kerja sama akan sulit dilakukan. Seorang atasan harus bisa melaksanakan tugasnya secara efektif. Untuk melaksanakan tugas yang efektif tentu diperlukan komunikasi yang efektif dengan bawahan. Komunikasi yang dikatakan efektif itu adalah ketika bawahan melaksanakan tugasnya dengan penuh kesadaran dan tanpa paksaan.

Peran individu dalam organisasi dituntut untuk selalu berinteraksi dan berkomunikasi satu sama lain, baik itu antara bawahan dengan atasan (upward communication), atasan dengan bawahan (downword communication), dan komunikasi setara (horizontal). Dengan begitu aliran informasi berjalan lancar sehingga membentuk iklim komunikasi organisasi yang berkembang sesuai dengan misi organisasi.

Untuk mewujudkan komunikasi yang efektif, organisasi sangat bergantung pada iklim yang berlangsung. Hal ini yang menjadi alasan penulis melakukan penelitian ini. Dengan adanya iklim organisasi yang relavan maka akan menumbuhkan rasa tanggung jawab, rasa persaudaraan, semangat antar pegawai. Iklim yang baik akan sangat mendukung pegawai dalam pelaksanaan tugasnya dan tanpa ada iklim yang bdik tentu akan berpengaruh pada kinerja individu dalam organisasi. Sama halnya yang terjadi di kantor Imigrasi Kelas II Lhokseumawe, atasan kurang memperhatikan karyawan dalam bekerja dan kurang ada motivasi yang diberikan pada karyawan, tentu hal ini akan sulit untuk menciptakan suasana kerja yang kondusif. Iklim komunikasi sangat diperlukan, karena proses komunikasi yang efektif sangat bergantung pada iklim komunikasi dalam organisasi. Karena itulah peneliti merasa tertarik untuk meneliti tentang iklim komunikasi organisasi dan melihat bagaimana iklim komunikasi yang berlangsung dikantor Imigrasi, meninjau lebih jauh bagaimana iklim komunikasi keatas, kebawah dan iklim komunikasi yang terjadi antara orang-orang yang sama tingkatannya di kantor tersebut. 
Dalam penelitian ini penulis melakukan penelitian dikantor Imigrasi Kelas II Lhokseumawe. Kantor imigrasi adalah salah satu kantor pemerintahan yang bergerak dibidang jasa pembuatan paspor dan hal-hal yang bersangkutan dengan imigrasi. Kegiatan umum di kantor Imigrasi Kelas II Lhokseumawe adalah memberikan pelayanan keimigrasian kepada masyarakat umum maupun Warga Negara Asing (WNA) yang berada dalam wilayah Indonesia. Selain itu, imigrasi juga memilki tugas dalam penegakan hukum yang berfokus pada kegiatan perpindahan sementara atau perpindahan secara permanen baik warga negara indonesia yang berpindah ke luar negeri ataupun sebaliknya.

Berdasarkan hasil observasi sementara yang penulis lakukan dikantor Imigrasi kelas II Lhokseumawe, penulis melihat bahwa komunikasi organisasi yang terjadi dikantor tersebut mengalami beberapa kendala, seperti komunikasi yang terjadi antara atasan dengan bawahan, atasan yang lebih bersikap individualis atau kurang memiliki kedekatan langsung dengan bawahan, atasan yang kurang memperhatikan dan kurang adanya motivasi yang diberikan oleh atasan terhadap bawahan. Dengan adanya kendala dalam berkomunikasi tersebut maka dapat menyebabkan beberapa pekerjaan tidak terkoordinasi dengan baik sehingga pekerjaan menjadi kurang efektif. Selain itu para bawahan juga lebih menfokuskan pada tugasnya masing-masing sehingga kurang ada interaksi antar karyawan yang lebih membangun iklim komunikasi yang baik. Hal inilah yang menimbulkan pertanyaan apakah iklim komunikasi di kantor Imigrasi Kelas II Lhokseumawe berjalan kondusif.

\section{Landasan Teoritis}

\section{Konsep Iklim Komunikasi Organisasi}

Pengertian iklim dalam Kamus Besar Bahasa Indonesia Terbitan Departemen Pendidikan Nasional (1999) dalam Nur Fadilah (2014) adalah 'Keadaan cuaca (suhu, kelembaban ,perawanan, hujan, dan sinar matahari) pada suatu daerah tertentu dalam waktu yang lama ( \pm 30 tahun) di suatu daerah, suasana; keadaan: kita mengusahakan stabilitas ekonomi agar tercapai kerja yg baik',

Dengan demikian dapat disimpulkan pengertian iklim adalah suatu keadaan atau suasana yang dapat mempengaruhi perubahan sikap dan sifat dari individu maupun kelompok dalam suatu wilayah tertentu. 
Pace \& Faules (2002) berpendapat bahwa iklim komuniakasi organisasi terdiri dari persepsi-persepsi atas unsurunsur organisasi dan pengaruh unsur-unsur tersebut terhadap komunikasi yang kemudian disepakati dan dikembangkan melalui interaksi dengan anggota organisasi lainnya.

Menurut muhammad (2007:82), iklim komunikasi dan organisasi merupakan hal yang perlu menjadi perhatian seorang pimpinan organisasi karena faktor tersebut banyak sedikitnya ikut mempengaruhi kepada tingkah laku karyawan.

Payne dan Pugh (Muhammad 2007:82) mendefinisikan iklim organisasi sebagai suatu konsep yang merefleksikan isi dan kekuatan dari nilai-nilai umum, norma, sikap, tingkah laku dan perasaan anggota terhadap suatu sistem sosial. Iklim komunikasi erat kaitannya dengan keterbukaan dalam berkomunikasi antar individu yang ada didalam organisasi. selain itu proses dalam berkomunikasi juga akan mempengaruhi iklim komunikasi yang berlangsung, seperti proses penyampaian instruksi, proses penyampaian ide juga kepercayaan antar setiap pelaku organisasi. (Muhammad 2007:82)

Iklim komunikasi dapat dipelajari dengan mengobservasikan jumlah otonomi secara individual, kebebasan yang dialami oleh individu, tingkat dan kejelasan struktur dan posisi yang dibebankan kepada pekerja, orientasi ganjaran dari organisasi dan banyaknya sokongan serta kehangatan yang diberikan kepada pekerja.

Iklim komunikasi yang sesuai penting bagi kelangsungan sebuah organisasi, dengan mengetahuinya kita dapat memahami anggota organisasi beserta harapannya. untuk itu iklim komunikasi dirasakan penting dalam sebuah organisasi karena tanpa kita sadari iklim komunikasi sebuah organisasi mempengaruhi cara hidup kita seperti kepada siapa kita berbicara, siapa yang kita sukai dan bagaimana cara kita menyesuaikan diri dengan organisasi.

Redding mengatakan bahwa iklim komunikasi organisasi jauh lebih penting dari pada keterampilan atau teknik-teknik komunikasi semata-mata dalam menciptakan suatu organisasi yang efektif (Pace \& Faules, 2002). Dengan mengaitkan pada individuindividu dalam organisasi peningkatan kualitas tiap individu yang dapat tercapai karena menurut Davis, iklim yang lebih pada manusia menghasilkan tingkat prestasi yang lebih tinggi dan kepuasan kerja yang lebih besar. Iklim yang baik akan lebih 
meningkatkan kepuasan kerja sehingga akan lebih memotivasi karyawan untuk bekerja lebih efektif.

\section{Arus Komunikasi dalam Organisasi}

Harun (2008 : 45) ia mengatakan dalam komunikasi organisasi, berbicara tentang informasi yang berpindah secara formal dari seseorang yang otoritasnya lebih tinggi kepada orang lain yang otoritasnya lebih rendah (komunikasi kebawah). Informasi yang bergerak dari suatu jabatan yang otoritasnya lebih rendah kepada orang yang otoritasnya lebih tinggi disebut komunikasi keatas. Informasi yang bergerak diantara orang-orang yang jabatan-jabatan sama tingkat otoritasnya disebut komunikasi horizontal.

\section{Komunikasi ke bawah}

Menurut Harun (2008:45) Komunikasi ke bawah mengalir dari orang pada jenjang hierarki yang lebih tinggi kejenjang yang lebih rendah. Bentuk yang paling umum adalah intruksi, memo resmi, pertanyaan tentang kebijakan perusahaan, prosedur, pedoman kerja dan pengumuman perusahaan. Komunikasi ke bawah menunjukan arus pesan yang mengalir dari para atasan atau para pimpinan kebawahannya kebanyakan komunikasi kebawah digunakan untuk menyampaikan pesan-pesan yang berkenaan dengan tugas-tugas dan pemeliharaan. Pesan tersebut biasanya berhubungan dengan pengarahan, tujuan, disiplin, perintah, pertanyaan dan kebijakan umum.

(Muhammad, 2007 : 108) Menurut Lewis komunikasi kebawah adalah untuk menyampaikan tujuan, untuk merubah sikap, membentuk pendapat, mengurangi ketakutan dan kecurigaan yang timbul karena salah informasi, mencegah kesalahpahaman karena kurang informasi dan mempersiapkan anggota organisasi untuk menyesuaikan diri dengan perubahan.

a. Tipe komunikasi kebawah

1) Instruksi tugas

Instruksi tugas/ pekerjaan yaitu pesan yang disampaikan kepada bawahan mengenai apa yang diharap dilakukan mereka dan bagaimana melakukannya. Pesan itu mungkin bervariasi seperti perintah langsung, deskripsi tugas, proseudurmanual, program latihan tertentu, alat-alat bantu melihat dan mendengar yang berisi pesan-pesan tugas dan sebagainya.

2) Rasional 
Rasional pekerjaan adalah pesan yang menjelaskan mengenai tujuan aktivitas dan bagaimana kaitan aktivitas itu dengan aktivitas lain dalam organisasi atau objektif organisasi. Kualiatas dan kuantitas dari komunikasi rasional ditentukan oleh filosofi dan asumsi pimpinan mengenai bawahannya. Bila pimpinan menganggap bawahannya pemalas atau hanya mau bekerja bila dipaksa maka pimpinan memberikan pesan yang bersifat rasional ini sedikit. Tetapi bila pimpinan menganggap bawahan orang yang dapat memotivasi diri sendiri dan produktif maka diberikan pesan rasional yang banyak.

3) Ideologi

Pesan mengenai ideologi ini merupakan perluasan dari pesan rasional. Pada pesan rasional penekanannya ada pada penjelasan tugas dan kaitannya dengan perspektif organisasi. Sedangkan pada pesan ideologi sebaliknya mencari sekongan dan antusias dari anggota organisasi guna memperkuat loyalitas, moral dan motivasi.

4) Informasi

Pesan informasi yang dimaksudkan untuk memperkenalkan bawahan dengan praktik-praktik organisasi, peraturanperaturan organisasi, keuntungan, kebiasaan dan data lain yang tidak berhubungan dengan intruksi dan rasional.

5) Balikan

Balikan adalah pesan yang berisi informasi mengenai ketepatan individu dalam melakukan pekerjaannya. Salah satu bentuk sederhana dari balikan ini adalah pembayaran gaji karyawan yang telah siap melakukan pekerjaannya, apabila tidak ada informasi dari atasan yang mengkritik pekerjaannya, berarti pekerjaannya sudah memuaskan. Tetapi apabila hasil pekerjaan karyawan kurang baik balikannya mungkin berupa kritikan atau peringatan terhadap karyawan tersebut.

b. Faktor yang mempengaruhi komunikasi kebawah

Arus komunikasi dari pada atasan kepada bawahan tidaklah selalu berjalan lancar tetapi dipengaruhi oleh berbagai faktor antara lain :

1) Keterbukaan

Kurangnya sifat terbuka antara pimpinan dan karyawan akan terjadi pemblokan, tidak mau menyampaikan pesan 
dan gangguan dalam pesan. Umumnya para pimpinan tidak begitu memperhatikan arus komunikasi kebawah. Pimpinan mau memberikan informasi kebawah bila mereka merasa bahwa pesan itu penting bagi penyelesaian tugas.

2) Kepercayaan pada pesan tulisan

Kebanyakan para pimpinan lebih percaya pada pesan tulisan dan metode difusi yang menggunakan alat-alat elektronik dari pada pesan yang disampaikan secara lisan dengan tatap muka. Hal ini menjadikan pimpinan lebih banyak menyampaikan pesan secara tertulis berupa buletin dan lain sebagainya sebagai pengganti kontak personal secara tatap muka antara atasan dan bawahan.

3) Pesan yang berlebihan

Karena banyaknya pesan-pesan dikirimkan secara tertulis maka karyawan dibebani dengan memo-memo, buletin, surat-surat pengumuman, majalah dan pernyataan kebijaksanaan, sehingga banyak sekali pesan-pesan yang harus dibaca oleh karyawan. Reaksi karyawan terhadap pesan tersebut biasanya cenderung tidak membacanya. Banyak karyawan yang hanya membaca pesan tertentu yang dianggap penting bagi dirinya dan yang lain tidak dibacanya.

4) Timing

Timing atau ketepatan waktu pengiriman pesan mempengaruhi komunikasi kebawah. Pimpinan hendaklah mempertimbangkan saat yang tepatbagi pengiriman pesan dan dampak yang potensial kepada tingkah laku karyawan. Pesan seharusnya dikirim kebawah pada saat saling menguntungkan pada kedua belah pihak. Tetapi bila pesan yang dikirimkan tersebut tidak pada saat dibutuhkan oleh karyawan maka mungkin akan mempengaruhi pada efektivitasnya.

5) Penyaringan

Pesan yang dikirimkan kepada bawahan tidaklah semuanya diterima mereka. Tetapi disaring yang mana yang mereka perlukan. Penyaringan pesan ini dapat disebabkan oleh bermacam-macam faktor diantaranya perbedaan persepsi diantara karyawan, jumlah mata rantai dalam jaringan komunikasi dan perasaan kurang percaya kepada supervisor. (Muhammad, $2007: 110$ ) 


\section{Komunikasi keatas}

Menurut Muhammad (2007: 116) Komunikasi keatas merupakan pesan yang mengalir dari bawahan kepada atasan atau dari tingkat yang lebih rendah kepada tingkat yang lebih tinggi. misalnya dari karyawan kemanajernya. Tujuan dari komunikasi ini adalah untuk memberikan balikan, memberikan saran dan mengajukan pertanyaan.

a. Fungsi Komunikasi ke Atas

1) Dengan adanya komunikasi keatas supervisor dapat mengetahui kapan bawahannya siap untuk diberi informasi dari mereka dan bagaimana baiknya mereka menerima apa yang disampaikan karyawan.

2) Arus komunikasi keatas memberikan informasi yang berharga bagi pembuatan keputusan.

3) Komunikasi keatas memperkuat apresiasi dan loyalitas bawahan terhadap organisasi dengan jalan memberikan kesempatan untuk menanyakan pertanyaan, mengajukan ideide dan saran-saran tentang jalannya organisasi.

4) Komunikasi keatas dapat menentukan apakah bawahan bisa menangkap apa yang di maksud supervisor waktu komuikasi kebawah terjadi.

5) Komunikasi keatas membantu karyawan mengatasi masalahmasalah pekerjaan mereka dan memperkuat keterlibatan mereka dalam tugasnya.

b. Faktor yang mempengaruhi efektivitas komunikasi keatas

1) Komunikasi keatas lebih mungkin digunakan oleh pembuat keputusan pengelolaan, apabila pesan disampaikan tepat pada waktunya. Pembuatan keputusan bukanlah aktivitas yang terus menerus. Oleh karena itu ketetapan data yang sampai pada saat pembuatan keputusan lebih mungkin akan digunakan dari pada data yang terlambat.

2) Komunikasi keatas yang bersifat positif, lebih mungkin digunakan oleh pembuat keputusan mengenai pengelolaan daripada komunikasi yang bersifat negatif. Oleh karena itu ada kecenderungan yang konsisten dari manajer tingkat menengah untuk meneruskan penyempaian komunikasi keatas yang bersifat positif dan mengabaikan atau menekan informasi yang bersifat negatif.

3) Komunikasi keatas lebih mungkin diterima, jika pesan itu mendukung kebijaksanaan yang baru. 
4) Komunikasi keatas mungkin akan lebih efektif, jika komunikasi itu langsung kepada penerima yang dapat berbuat mengenai hal itu.

5) Komunikasi keatas akan lebih efektif, apabila komunikasi itu mempunyai daya tarik secara intuitif bagi penerima.

Komunikasi keatas merupakan sumber informasi yang penting dalam membuat keputusan, karena adanya komunikasi ini pimpinan dapat menegtahui bagaimana pendapat bawahan mengenai atasan, mengenai pekerjaan mereka, mengenai temantemannya kerjanya dan mengenai organisasi. (Muhammad, 2007: 119)

\section{Komunikasi Horizontal}

Komunikasi horizontal adalah pertukaran pesan diantara orang-orang yang sama tingkatan otoritasnya didalam organisasi. Pesan yang mengalir menurut fungsi dalam organisasi diarahkan secara horizontal. Pesan ini biasanya berhubungan dengan tugastugas atau tujuan kemanusiaan seperti koordinasi, pemecahan masalah, penyelesaian konflik dan saling memberikan informasi. Muhammad (2007 : 121)

a. Tujuan Komunikasi Horizontal

1) Mengkoordinasikan tugas-tugas.

2) Saling berbagi informasi untuk perencanaan dan aktivitasaktivitas.

3) Memecahkan masalah yang timbul diantara orang-orang yang berada dalam tingkat yang sama.

4) Menyelesaikan konflik diantara anggota yang ada dalam bagian organisasi dan juga antara bagian satu dengan bagian lainnya.

5) Menjamin pemahaman yang sama.

6) Mengembangkan sokongan interpersonal.

b. Masalah dalam komunikasi Horizontal

Komunikasi horizontal sangat penting untuk koordinasi pekerjaan antara bagian-bagian dalam organisasi. Akan tetapi bagian-bagian itu sendiri mungkin menghalangi komunikasi horizontal. Keterbatasan informasi menambah kekuasaan bagi pimpinan untuk berkuasa. Dengan meningkatkan keterbatasan komunikasi horizontal, bawahan menjadi tergantung pada informasi yang disampaikan secara vertikal. 
Komunikasi horizontal berkembang serta tidak terkontrol, karena struktur organisasi mempunyai lebih banyak bagian-bagian dan setiap individu makin mempunyai spesialisasi tertentu, kebutuhan akan koordinasi bagian-bagian menambah komunikasi horizontal.komunikasi horizontal bertambah karena kekuasaan atau otoritas sentralisasi menjadi berkurang. (Muhammad, 2007 : 124)

Menurut Harun (2008 : 49) komunikasi horizontal muncul karena enam alasan.

1. Untuk mengkoordinasikan penugasan kerja. Para anggota bagian pelatihan dan pengembangan memiliki kegiatan pelatihan utama untuk mengatur dan menyampaikan. Mereka harus saling bertemu untuk mengkoordinasikan pembagian tugas.

2. Berbagi informasi mengenai rencana dan kegiatan. Bila gagasan dari beberapa orang menjanjikan hasil yang lebih baik dari pada gagasan satu orang, komunikasi horizontal menjadi amat penting.dalam menciptakan rancangan suatu program anggota suatu bagian perlu berbagi informasi mengenai rencana mereka dan apa yang akan mereka kerjakan.

3. Untuk memecahkan masalah.

4. Untuk memperoleh pemahaman bersama.

5. Untuk mendamaikan, berunding dan menengahi perbedaan. Individu-individu sering mengembangkan pilihan dan prioritas yang akhirnya menimbulkan ketidak-sepakatan. Bila hal ini terjadi komunikasi horizontal merupakan hal pokok dalam mendamaikan perbedaan. Beberapa perbedaan perlu dirundingkan dan didamaikan dan hanya dengan melalui komunikasi horizontal prioritas dapat disesuaikan dan konflik diselesaikan.

6. Untuk menumbuhkan dukungan antar-persona

\section{Metode Penelitian}

Penelitian peneliti ini menggunakan pendekatan kualitatif. Artinya dalam penelitian ini, perhatian penulis lebih tertuju kepada permasalahan-permasalahan yang berhubungan dengan iklim komunikasi organisasi dan menfokuskan pada iklim komunikasi dari atasan kebawahan, bawahan keatasan dan komunikasi horizontal atau sama tingkat otoritasnya. Pendekatan penelitian bersifat kualitatif karena data yang penulis peroleh dengan cara 
mengkaji dan menggambarkan proses iklim komunikasi organisasi secara realita dan bukan dalam bentuk bilangan ataupun angka.

Dalam penelitian ini penulis menentukan informan dengan teknik purposive sampling, yaitu teknik penentuan informan dengan pertimbangan tertentu menurut kriteria yang telah ditetapkan, kriteria itu adalah informan yang merupakan pegawai di bidang yang proses kerjanya saling terhubung dari proses pengambilan foto, wawancara dan kemudian baru penyerahan di bagian loket pelayanan, selain itu juga setiap hari nya bertugas melayani masyarakat dalam proses pembuatan paspor hingga akhir, sebanyak 60 antrian perhari.

Berdasarkan kriteria ini yang menjadi informannya adalah 3 pegawai kantor Imigrasi dan satu orang Kepala Urusan Wasdakim (Pengawasan dan Penindakan Keimigrasian). Kriteria ini sesuai dengan topik penelitian penulis untuk menjawab masalah penelitian yang dilakukan. Mereka dapat memberikan jawaban terhadap rumusan masalah dalam penelitian ini, maka peneliti memilih informan yang sesuai dengan kriteria yang disebutkan diatas.

\section{Hasil Penelitian dan Pembahasan Gambaran Lokasi Penelitian}

Kelahiran kantor Imigrasi Kelas II Lhokseumawe tidak dapat diketahui secara pasti. Namun diperkirakan kantor Imigrasi Lhokseumawe lahir pada tahun 1964 yang ketika itu bernama Kantor Imigrasi Daerah $1 / 2$ Lhokseumawe (Kanamida 1/2 Lhokseumawe) berada di Kota Lhokseumawe, yang memiliki segudang cerita suka dan duka dengan mengalami berbagai perubahan, seperti perubahan nama kantor, perpindahan antara dua tempat kantor, dan pergantian pimpinan.

Pada saat itu wilayah Kanamida 1/2 Lhokseumawe meliputi kabupaten Aceh Utara, Aceh Tengah, Aceh Timur dan Aceh Tenggara dengan masing - masing daerah memiliki berbagai macam persoalan dan perbedaan sosial budaya. Di sebelah timur (kabupaten Aceh Timur dan Aceh Tenggara) berbatasan dengan Sumatera Utara, sebelah barat berbatasan dengan kabupaten Pidie, diselatan (kabupaten Aceh Tengah) berbatasan dengan kabupaten Aceh Selatan dan Aceh Barat, dan di utara dengan Malaysia dibatasi dengan Selat Malaka. Sesuai dengan perkembangan zaman nama kantor imigrasi Daerah $1 / 2$ Lhokseumawe berubah nama 
menjadi kantor Imigrasi Daerah Lhokseumawe (Kanimida Lhokseumawe).

Pada masa itu kanimida Lhokseumawe masih belum juga memiliki gudang atau kantor sendiri, sehingga proses pelayanan, pengawasan, dan penegakan hukum yang diberikan juga berjalan apa adanya. Kemudian pada awal tahun 1970 kantor Imigrasi daerah Lhokseumawe telah memiliki kantor sendiri yang berada dijalan Pelabuhan No.1 Lhokseumawe (kini menjadi ruang penyimpanan arsip subtantif keimigrasian). Walaupun sudah memiliki kantor sendiri dengan personil 5 orang pegawai termasuk kepala kantor tetapi aktifitas pelayanan keimigrasian masih berjalan lancar.

Pada tahun 1970-an kantor imigrasi Daerah Lhokseumawe berubah nama menjadi Resort Imigrasi Lhokseumawe. Karena luasnya wilayah kerja dan banyaknya tugas harus dilaksanakan, maka sekitar tahun 1974 dibukalah pos Imigrasi di kota langsa untuk membantu masyarakat yang berada di kabupaten Aceh Timur dan Aceh Tenggara, termasuk pengawasan dan penegakan hukumnya.

Kantor Imigrasi Kelas II Lhokseumawe sering berpindah tempat antara gedung lama. Awal tahun 2006 sampai januari 2008 menempati gedung baru dijalan raya Medan - Banda Aceh, kemudian Februari 2008 atas berbagai pertimbangan kembali menempati gedung lama dijalan Pelabuhan No. 5 Lhokseumawe hingga sekarang.

Dengan diterbitkan Surat Keputusan Menteri Hukum dan Hak Asasi Manusia Nomor : M-HH-03.OT.01.01 tahun 2012 tentang pembentukan kantor Imigrasi Kelas III Takengon dan kantor Imigrasi Kelas II Labuan Bajo tanggal Mei 2012. Maka sejak itulah wilayah kerja kantor Imigrasi Kelas II Lhokseumawe telah berkurang dan menjadi wilayah kerja kantor Kelas III Takengon. Sehingga wilayah kerja kantor Imigrasi Kelas II terdiri dari pemerintahan Kota Lhokseumawe sendiri dan 2 pemerintah kabupaten yaitu kabupaten Aceh Utara dan Kabupaten Bireuen

\section{Iklim Komunikasi Organisasi di Kantor Imigrasi Kelas II Lhokseumawe}

Iklim komunikasi dan organisasi merupakan hal yang perlu menjadi perhatian seorang pimpinan organisasi, karena faktor ini banyak sedikitnya ikut mempengaruhi kepada tingkah laku anggota 
organisasi. Untuk dapat menciptakan iklim komunikasi dan organisasi yang baik, perlu memahami hal tersebut serta keadaan pelaku organisasi.

Iklim Organisasi dipengaruhi oleh bermacam-macam cara anggota organisasi bertingkah laku dan berkomunikasi. Iklim komunikasi yang penuh persaudaraan mendorong para anggota organisasi berkomunikasi secara terbuka, rileks, ramah tamah. Komunikasi yang baik juga akan sangat berdampak pada anggota organisasi.

Berdasarkan hasil observasi, penulis menemukan beberapa kendala seperti komunikasi yang terjadi antara atasan dengan bawahan, atasan yang lebih bersikap individualis atau kurang memiliki kedekatan langsung dengan bawahan, atasan yang kurang memperhatikan dan kurang adanya motivasi yang diberikan oleh atasan terhadap bawahan. Pada wawancara yang peneliti lakukan dengan Kepala Urusan Wasdakim (Pengawasan dan penindakan Keimigrasian) mengungkapkan bahwa beliau jarang berkomunikasi dengan bawahan dikarenakan Pekerjaan, berikut wawancara yang disampaikan oleh Bapak Yahya, beliau mengatakan bahwa :

"Komunikasi yang ada di kantor imigrasi ini berjalan baik, selama ini kendalanya tidak ada yang sesegnifikan dan sampai saat ini lancar-lancar saja. Kalau dengan bawahan kadang pada saat ada permasalahan saja kami ada komunikasi karena, saya juga sibuk ada kerjaan yang harus saya selesaikan, jadi apabila ada pemohon yang mengalami kendala atau data yang berbeda atau kendala lain yang berhubungan dengan perlengkapan berkas baru mereka melaporkan kepada saya, terlebih dahulu penyampaian nya secara lisan dulu setelahnya baru memperlihatkan berkasnya". (wawancara, Senin, 29 Januari 2018).

Dari hasil wawancara penulis dengan Kepala Urusan Wasdakim (Pengawasan dan Penindakan Keimigrasian) dapat diketahui bahwa iklim komunikasi yang berlangsung di kantor Imigrasi Kelas II Lhokseumawe memang tidak ada kendala, proses komunikasinya juga tidak ada hambatan yang sesegnifikan. Namun, atasan jarang berkomunikasi dengan bawahan, komunikasi yang berlangsung antara atasan dengan bawahan hanya terjadi 
ketika ada permasalahan saja. Selain itu, atasan juga sibuk dengan pekerjaan yang harus diselesaikan menyebabkan proses komunikasi jarang terjadi. Ketika ada permasalahan yang berkenaan dengan pekerjaan seperti ada kendala dengan pekerjaan bawahan, baru bawahan mengkomunikasikannya ke atasan.

Komunikasi yang berlangsung direspon dengan baik oleh atasan, Seperti yang di ungkapkan Ibu Almaul Husna dalam wawancara yang penulis lakukan Senin, 29 Januari 2018, beliau mengatakan bahwa :

"kalau untuk iklim komunikasinya cukup baik, karena komunikasi dari atasan dan dari bawahan keatasan berjalan baik, sesama staf juga lancar komunikasinya, dan selalu dikomunikasikan dengan baik kalau ada masalah, baik dengan atasan maupun sesama staf. Kalau kendala sih sejauh ini tidak ada, karena ketika ada kendala dengan pekerjaan langsung dikomunikasikan baik secara langsung ketika ada di ruangan maupun secara tidak langsung atau tidak ada ditempat juga bisa dikomunikasikan lewat telpon dan whatshap juga cepat responnya, jadi lancar-lancar aja komunikasinya".

Dari wawancara diatas menunjukan bahwa komunikasi dari atasan kebawahan terjadi ketika ada permasalahan dan kendala mengenai pekerjaan saja, hal ini disebabkan atasan yang sibuk dengan pekerjaannya yang menyebabkan komunikasi jarang terjadi, namun ketika ada kendala dengan pekerjaan bawahan, atasan selalu meresponnya dengan baik, baik itu ketika ada di kantor maupun ketika berada di luar, komunikasinya tetap berjalan walaupun menggunakan telpon, namun atasan selalu meresponnya dengan cepat.

Selanjutnya juga dijelaskan oleh Dicky Teguh, kepada peneliti bahwa : "Komunikasi berjalan baik. Atasan memberikan feedback yang baik atas semua saran dan pendapat dari bawahan". Pendapat yang sama juga dijelaskan oleh bapak Bayu kepada peneliti, beliau mengatakan bahwa :

"iklim komunikasinya baik sih, disini saling menghargai, ibaratnya kita sesuai dengan posisinya, kita berkomunikasi kalau tata cara penyampaian kita misalnya kita bawahan, gimana cara kita menyampaikan keatasan. Baik sih kalau iklim komunikasinya cukup 
baik disini, alhamdulillah sampai saat ini tidak ada bermasalah dengan iklim komunikasi, hanya kurang kumpul dan kurang berkomunikasi aja sama atasan karena atasan sibuk dengan pekerjaannya, tapi kami tetap menjaga iklim komunikasi yang ada”.

Dari beberapa hasil wawancara diatas dapat diketahui bahwa iklim komunikasi merupakan hal yang penting dalam organisasi. Imigrasi adalah kantor yang memang mengharuskan setiap pegawai menjaga iklim komunikasi, bukan hanya dengan sesama staf dan atasan saja tetapi juga dengan masyarakat, karena setiap hari pegawai selalu berhadapan langsung dengan masyarakat dalam proses pembuatan paspor, dengan menjaga iklim komunikasi yang baik tersebut akan memudahkan pegawai dalam melaksanakan tugasnya.

Iklim komunikasi yang berlangsung di kantor Imigrasi Kelas II Lhokseumawe yaitu komunikasi yang berlangsung kebawah hanya berlangsung pada saat ada permasalahan saja, hal ini disebabkan karena atasan yang sibuk dengan pekerjaan yang harus diselesaikan menyebabkan komunikasi ini jarang terjadi. Namun komunikasi tetap berjalan baik ketika bawahan menyampaikan kendala yang berhubungan dengan pekerjaannya, ini dilihat dari pernyataan ibu Asmaul Husna yang mengatakan bahwa komunikasi dengan atasan tetap berlangsung walaupun atasan tidak ditempat namun masih bisa mengkomunikasikannya menggunakan Handphone dan dilihat dari pernyataan pak Bayu dapat diketahui bahwa Iklim komunikasi yang berlangsung baikbaik saja, tidak ada masalah yang besar yang mempengaruhi iklim komunikasi di kantor ini hanya saja kurang komunikasi dengan atasan karena atasan sibuk dengan pekerjaan yang harus diselesaikan.

\section{Proses Komunikasi dan Keterbukaan dalam Berkomunikasi}

Komunikasi melibatikan tiga unsur yakni pengirim, media komunikasi dan penerima. Keefektifan komunikasi bergantung pada tiga unsur ini. Jika pengirim tidak berkompeten atau pesan yang disampaikan tidak jelas maka sipenerima tidak akan memahami makna dari tanda-tanda yang diberikan dan proses 
komunikasi itupun gagal. Proses komunikasi dan keterbukaan dalam memberi pendapat adalah salah satu bentuk dari iklim komunikasi yang baik, semakin besar tingkat keterbukaannya maka semakin berdampak baik pada pekerjaan pegawai.

Setelah penulis meninjau langsung kelapangan, dalam proses komunikasi dan keterbukaan dalam memberi pendapat, bawahaan tidak sepenuhnya mengutarakan keluhannya, berikut dijelaskan oleh bapak Yahya dalam wawancara yang penulis lakukan, beliau mengatakan :

"Yang saya lihat sekarang, bawahan itu kalau tidak ditanya jarang menyampaikan, jadi tunggu ada saya panggil dulu baru mereka mau mengutarakan keluhannya, jadi kalau secara langsung mungkin jarang, mereka tidak terbuka $100 \%$, kalau saya tanya baru mereka menyampaikannya".

Selain itu bapak Yahya juga mengatakan bahwa :

"Saya memang jarang memberikan arahan kepada bawahan karena bawahanpun sudah mengerti apa yang dikerjakannya, dan ketika ada permasalahan, saya berkomunikasi perindividu, jarang saya memberikan dan mengumpulkan bawahan dalam wadah rapat, dan misalkan ada permasalahan langsung saya panggilkan dan menyampaikannya langsung kepada orang yang bersangkutan". (wawancara 29 Januari 2018 )

Dari hasil wawancara diatas terlihat bahwa ketika atasan tidak bertanya maka bawahanpun jarang menyampaikan keluhan, bawahan tidak sepenuhnya terbuka kepada atasan, tunggu atasan yang bertanya dulu baru bawahan mengutarakan keluhan. Selain itu atasan juga jarang memberikan arahan kepada bawahan karena menurut atasan, bawahan sudah mengerti dengan masing-masing tugasnya dan ketika ada permasalahan, baru bawahan mengkomunikasikannya disaat yang sama. Berikut yang disampaikan oleh Ibu Asmaul Husna, beliau mengatakan :

"Misalnya ada kendala dalam pekerjaan biasanya kita selalu mengkomunikasikannya disaat yang sama karena pengambilan keputusannya harus cepat karena kita berhubungan langsung dengan masyarakat. Dan untuk 
atasan pun, kalau memang ada ditempat ketika ada masalah selalu mengkomunikasikan nya secara cepat"

Hal yang senada juga di jelaskan oleh bapak Bayu, berikut kutipan wawancaranya :

"sejauh ini atasan saya cukup objektif, karena segala sesuatu bukan cuman dari bawahan keatasan, kadang beliau pun sering minta saran dan pendapat pegawai, juga sering menanyakan kendala yang berkenaan dengan pekerjaan jadi sudah terasa dekat sudah seperti rekan kerja". (Wawancara 29 Januari 2018)

Dalam hal yang sama juga dijelaskan oleh pak Dicky Teguh, dalam isi wawancaranya beliau menjelaskan :

"Proses komunikasi yang berlangsung dengan atasan dan rekan kerja sangat berjalan dengan baik, bukan hanya dengan atasan saja kami juga sangat menjaga komunikasi dengan sesama rekan kerja, karena kita saling menghargai satu sama lain juga sangat menghormati antar sesama rekan kerja dan juga sangat menghormati pendapat yang berbeda, sehingga tercipta sinergi dilingkungan kantor imigrasi ini”.

Proses komunikasi yang berlangsung keatasan yang ungkapkan oleh bawahan berjalan baik tidak hanya dengan atasan proses komunikasi horizontal atau yang terjadi dengan sesama rekan kerja juga berlangsung dengan lancar, para bawahan selalu memperhatikan proses komunikasi tidak hanya dengan atasan tetapi juga sangat memperhatikan proses komunikasi yang berlangsung denga rekan kerja. Sedangkan wawancara dengan atasan dapat dilihat bahwa keterbukaan dalam proses penyampaian pendapat atau keluhan keatasan belum sepenuh nya terbuka. bawahan selalu menunggu atasan yang bertanya baru mereka menyampaikannya, bawahan yang mengerti dengan tugas-tugasnya membuat atasan jarang melakukan komunikasi dan tidak lagi memberi arahan langsung kepada bawahan. Tetapi ketika ada kendala mengenai pekerjaan baru disampaikan ke atasan.

Atasan juga menganjurkan bawahan untuk memberitahu jika ada kesulitan mengenai pekerjaan, seperti yang di ungkapkan 
oleh bapak Dicky Teguh dalam wawancaranya dengan penulis Senin, 29 Januari 2018, beliau mengatakan :

"Atasan sangat menganjurkan untuk memberitahu jika ada kesulitan didalam bekerja, ini dikarenakan untuk bisa mewujudkan dan mencapai sistem kerja yang sesuai untuk melayani masyarakat".

Pendapat yang sama juga disampaikan oleh bapak bayu dalam hal ini beliau mengatakan :

"Iya, sangat menganjurkan karena permaslahan yang ada harus selalu didiskusikan kembali dan mencari jalan keluar dari setiap permasalahan mengenai pekerjaan”.

Dari wawancara diatas dapat diketahui bahwa untuk mewujudkan sistem kerja yang sesuai dengan yang diharapkan atasan sangat menganjurkan para bawahan untuk memberitahukan jika terdapat kesulitan dalam bekerja. Tidak hanya itu atasan juga berdiskusi dengan bawahan dan juga mencari jalan keluar dari setiap permasalahan.

Selain atasan yang sangat menganjurkan bawahan untuk memberitahu jika ada kendala dengan pekerjaan bawahan, atasan juga sangat menerima kritik dan saran dan juga ide atau gagasan dari bawahan seperti yang diungkapkan oleh pak Bayu, dalam wawancaranya beliau mengatakan :

"Sejauh ini atasan saya menerima, atasan saya cukup objektif, beliau selalu menerima kritik dan saran, dan kadang ketika atasan saya butuh pendapat atasan saya juga sering minta pendapat saya, ibaratnya kita sharing sama dia".

Pernyataan yang sama juga dijelaskan oleh Ibu Asmaul Husna, berikut wawancaranya :

"diterima, sejauh idenya tidak keluar dari peraturan kita tetap diterima dengan baik oleh atasan".

Kemudian pak DickyTeguh juga melanjutkan hal yang senada, berikut wawancaranya :

"Saran dan kritik harus dituangkan sesuai porsi dan bebean tugas masing-masing, sesuai hirarki di organisasi dan sejauh ini semua saran, kritik dan ide yang di sampaikan diterima dengan baik oleh atasan". 
Berikut wawancara langsung dengan pak Yahya, beliau mengatakan :

"iya,. ide atau gagasan dari bawahan itu biasanya saya tampung dulu setelahnya baru dipertimbangkan apakah ide tersebut bisa dilaksanakan atau tidak, Jadi tidak langsung saya iyakan atau saya tolak mentah-mentah ide dan gagasan dari bawahan".

Dari wawancara diatas dapat diketahui bahwa atasan sangat menerima ide/ gagasan dari para bawahan, dilihat dari pernyataan Pak Bayu atasan selalu objektif dalam menerima kritik/saran, atasan juga minta saran dari bawahan. Sama hal nya dengan pernyataan dari pegawai lainnya dapat diketahui bahwa atasan memang sangat menerima ide-ide dari para bawahan dan atasan akan mempertimbangkan ide tersebut apakah bisa dilaksanakan atau tidak

\section{Kesimpulan}

Iklim komunikasi adalah hal yang sangat penting dalam sebuah organisasi. dengan adanya iklim komunikasi yang baik akan sangat berpengaruh pada anggota organisasi. Iklim komunikasi organisasi di kantor Imigrasi Kelas II Lhokseumawe sudah berjalan dengan lancar, tidak ada kendala yang besar yang mempengaruhi keberlangsungan iklim komunikasi, hanya saja komunikasi yang berlangsung jarang disebabkan karena atasan yang sibuk dengan pekerjaannya, atasan juga jarang memberi pengarahan langsung kepada bawahan karena menurut atasan bawahan sudah mengerti dengan setiap tugas yang di embannya. Namun komunikasi tetap berjalan baik ketika bawahan menyampaikan kendala mengenai pekerjaan, baik ketika atasan ada maupun tidak ada ditempat.

Proses komunikasi yang terjadi di kantor Imigrasi berjalan baik, namun keterbukaan dalam berkomunikasi, bawahan tidak sepenuhnya terbuka, bawahan selalu menunggu atasan yang bertanya dulu baru menyampaikan keluhannya. Berbeda halnya pada saat terjadi permasalahan, pegawai mengkomunikasikannya kepada atasan pada saat yang bersamaan, selain itu atasan juga sangat mengajurkan bawahan memberitahu jika terjadi permasalahan mengenai pekerjaan bawahan. sehingga pemecahan masalahnya dan jalan keluar dari permasalahan yang berlangsung bisa secepatnya teratasi. 


\section{Daftar Pustaka}

Bungin, Burhan. 2007. Penelitian Kualitatif, Jakarta : Prenada Media Group

Cangara, Hafied, 2012. Pengantar Ilmu Komunikasi, Jakarta : PT Rajagrafindo Persada

Fajar, Marhaeni.2009.Ilmu Komunikasi Teori dan Praktek. Jakarta : Graha Ilmu

Fisher, B.Aubrey.1978. Teori - teori Komunikasi,Bandung : CV Remadja Karya

Harun, Rochajat. 2008. Komunikasi Organisasi, Bandung : Mandar Maju

Morissan.2009. Teori Komunikasi Organisasi, Jakarta : Ghalia Indonesia

Muhammad, Arni. 2007. Komunikasi Organisasi, Jakarta : PT Bumi Aksara

Mulyana, Deddy.2010.Metodologi Penelitian Kualitatif, Bandung : PT Ramaja Rosdakarya.

Pace, R.Wayne \& Don F. Faules (2002). Komunikasi Organisasi: Strategi Meningkatkan Kinerja Perusahaan. Bandung : PT Remaja Rosdakarya

Riswandi.2009. Ilmu Komunikasi, Yogyakarta : Graha Ilmu

Soetopo, Hendyat. 2010. Perilaku Organisasi, Bandung : PT Remaja Rosdakarya

Tangkilisan, Hessel Nogi,S.2005.Manajemen Publik.Jakarta : PT.Grasindo

Wiryanto. 2004. Pengantar Ilmu Komunikasi, Jakarta : PT Gramedia Widiasarana Indonesia

Nur Fadilah(2014). Iklim Komunikasi Organisasi Dalam Meningkatkan Kinerja Karyawan Di Perusahaan Manado Post.Jurnal Volume III. No.2. 